\title{
LA DELEGACIÓN CARLISTA DE MATÍAS BARRIO Y MIER (1899-1909). CONTINUISMO TRADICIONALISTA
}

\author{
The Carlist Delegation of Matias Barrio y Mier (1899-1909): \\ Traditionalist Continuity
}

\author{
Agustín Fernández Escudero ${ }^{1}$ \\ Universidad Complutense de Madrid
}

\section{Resumen}

El carlismo de los primeros años del siglo Xx estaba dirigido por Matías Barrio y Mier, un tradicionalista, abogado y catedrático, al que don Carlos - Carlos VII para los carlistas-, nombró su delegado en diciembre de 1899, tras la dimisión del marqués de Cerralbo. Este profesor continuó ejerciendo la representación carlista hasta su muerte en junio de 1909, dejando un partido que había superado la crisis de 1900 y que buscaba su propio espacio público. Por otro lado, se ha visto que a don Carlos en aquellos años le preocupaba, más que la situación política o económica de España, constatar que no estaba dispuesto a abdicar en su hijo don Jaime y que, en la última sublevación carlista de 1900, él no había tenido participación. Por tanto, se ha considerado necesario mostrar la defensa que hacía el pretendiente de sus derechos dinásticos, contextualizándola con los cruciales momentos de la Historia de España en los años de la delegación de Barrio y Mier.

Palabras clave: carlismo, don Carlos, Barrio y Mier, don Jaime, Feliú, marqués de Cerralbo

\section{Abstract}

The carlism of early twentieth century. Carlism directed by Matias Barrio y Mier, a traditionalist, a lawyer and professor, which don Carlos, Charles VII to the

1 Licenciado en Historia, Máster en Historia Contemporánea y Doctor en Historia por la Universidad Complutense de Madrid. Correo electrónico: affescudero@gmail.com. Fecha de recepción del artículo: 15 de noviembre de 2017. Fecha de aceptación: 27 de marzo de 2018. 
Carlists, named his deputy in December 1899, following the demission of the Marquis of Cerralbo. This teacher continued to exercise the Carlist representation until his death in June 1909, leaving a party that had overcome the crisis of 1900 and sought their own public space. On the other hand, it has been seen that don Carlos in those years was concerned, rather than the political situation or economic of Spain, finding that it was not willing to abdicate in his son don Jaime and the last Carlist uprising in 1900, he had not been involved. Therefore, it was considered necessary to show the defense that made the suitor of his dynastic rights, contextualizing the crucial moments in the history of Spain in the years of the delegation of Barrio y Mier.

Key words: carlism, don Carlos, Barrio y Mier, don Jaime, Feliú, Marquis of Cerralbo

\section{INTRODUCCIÓN}

En este artículo se tratará de aportar algo más de luz sobre la situación del carlismo en los primeros años del siglo Xx, después de que, tras el llamado «Desastre del 98», que motivó, además de los graves problemas económicos, sociales y militares en toda la nación, que los carlistas iniciaran la que sería su última intentona de llegar al poder de forma violenta y que propició, en 1900, la llamada «Octubrada», resultando un fiasco con graves consecuencias para el partido. Don Carlos, (duque de Madrid y Carlos VII para los carlistas) por su parte anunciaba que él, en contra de los rumores o noticias publicadas, no había tenido nada que ver en esta sublevación, aunque no dudaba en decir que él había pensado en algo más importante. Asimismo, en diciembre de 1899, el marqués de Cerralbo ${ }^{2}$ había dimitido de su cargo como delegado en España de don Carlos. Momento en que, el rey, más preocupado por las intrigas de los seguidores de su hijo don Jaime para que este ocupara su puesto de pretendiente al trono español, no eligió a ningún carlista con corona de conde o marqués, sino que nombró como sucesor del noble madrileño al palentino, abogado y catedrático, Matías Barrio y Mier (1844-1909). A la vez que se irá relatando cronológicamente la vida política de Barrio y Mier, mezclada con puntuales menciones a sus otras ocupaciones, se mostrará, desde una óptica tradicionalista, los acon-

2 Enrique de Aguilera y Gamboa, XVII marqués de Cerralbo (Madrid 1845-1922) tradicionalista desde la cuna, fue delegado de don Carlos desde abril de 1890 hasta diciembre de 1899. En noviembre de 1912, don Jaime nombró a Cerralbo presidente de una Junta Superior Central Tradicionalista. 
tecimientos de los años que comprendieron la delegación de este prolífico delegado.

Además de otras fuentes que puntualmente se irán citando, para este trabajo se ha partido de la escasa bibliografía existente referida a Barrio y Mier y de las noticias aparecidas en prensa que lo citaban en sus tareas como delegado de don Carlos; y como diputado defendiendo en el Congreso causas relacionadas con la religión o con los problemas de su jurisdicción palentina; pero también ejerciendo como abogado y en su ocupación académica. Pero principalmente, se han utilizado, como fuente primaria, las cartas inéditas que don Carlos, desde su veneciano palacio del Loredán, envió a Barrio y Mier durante los años de su delegación, es decir, desde 1899 hasta 1909. Esta correspondencia fue encontrada en una investigación realizada en el madrileño Archivo del Museo Cerralbo, a donde había llegado donada por un descendiente del diputado palentino. ${ }^{3}$ Por el contrario, no se sabe cómo le contestaba el representante al pretendiente, porque no se han podido localizar las cartas que le dirigió, dado que doña Berta, su segunda esposa del rey, después de la muerte de éste, en julio de 1909, además de haber quemado muchos documentos, vendió el palacio y su contenido a distintos anticuarios.

\section{Matías Barrio y Mier. UNA VIDA ENTRE EL CARLISMO Y LA UNIVERSIDAD}

Matías Barrio y Mier (Verdeña-Palencia 10-2-1844 - Madrid 23-6-1909) fue un jurisconsulto, catedrático y político tradicionalista, proveniente de una familia carlista y religiosa. Demostrando su devoción a la Causa bautizó a tres de sus cuatro hijos con nombres tan carlistas como: Carlos, Jaime y Blanca. ${ }^{4}$

En lo relativo a su vida política, la primera vez que Barrio y Mier se presentó en unas elecciones fue en 1869 con la candidatura monárquicocatólica, pero no logró el éxito. Sin embargo, siguiendo como carlista y por Cervera de Pisuerga, sí resultó elegido en la legislatura de 1871, siendo el diputado más joven de su época, y teniendo múltiples intervenciones en el

3 Según lo manifestado, en 2009, por Pilar Calzas, documentalista de esta institución.

4 Santiago Francia Lorenzo: «Territorio Perniano. Un manuscrito de Matías Barrio y Mier en el Archivo Capitular de Palencia», Publicaciones de la Institución Tello Téllez, 71 (2000): 455-468. 
Congreso. ${ }^{5}$ Fue secretario de alguna sección y participó en la elaboración de distintas leyes, hasta que, en abril de 1872, con motivo de la última guerra carlista y siguiendo las órdenes de don Carlos, que lo había nombrado corregidor de Vizcaya, renunció a su escaño. ${ }^{6}$ Tuvo que abandonar España, para más adelante, desde Francia, entrar en el territorio del norte peninsular dominado por los tradicionalistas. Allí desempeñó, entre otras labores didácticas, la de decano de la restablecida Universidad de Oñate. Barrio y Mier volvió a Francia y regresó a España en 1877, una vez terminada la guerra (1872-1876).

Con respecto a su vida académica, en el Diccionario Biográfico Espanol aparece una completa descripción de su historia universitaria. En la misma se citan sus primeros estudios universitarios en Valladolid (18591865), donde llegó a ser dos meses catedrático sustituto; más adelante, trasladó su expediente a la Universidad Central de Madrid, donde fue investido doctor de Derecho Civil Canónico en 1866, además de otros doctorados en Derecho Administrativo y en Filosofía y Letras; y añadido a sus excelentes notas, ejerció como redactor de revistas universitarias. Como profesor titular ejerció en las universidades de Vitoria, Zaragoza y en la Universidad Central, impartiendo distintas materias. Como se ha dicho, durante la guerra carlista fue catedrático en la Universidad de Oñate.

Terminada la contienda carlista, después de múltiples gestiones para que le fueran reconocidos sus derechos y que se obviara su paso por Oñate, finalmente le fue asignada, por oposición, la cátedra de Derecho Romano en la universidad de Valencia (1880-1881), y más adelante, fue nombrado decano de la facultad de Derecho de la Universidad de Oviedo (1881-1886). ${ }^{8}$ En 1886, fue nombrado académico de la Academia Matritense de Jurisprudencia, para pasar a ser decano de la Facultad de Derecho de la Universidad Central, hasta su fallecimiento. ${ }^{9}$

5 Congreso de Diputados, Índice Histórico de Diputados, indica que, en estas elecciones del 8 de marzo de 1871, Barrio y Mier logró 5.252 votos a su favor.

6 Posteriormente, como se irá desarrollando, Barrio y Mier fue elegido diputado en las elecciones de 1891, 1893, 1896, 1898, 1899, 1901, 1905 y 1907, Congreso de Diputados, Índice Histórico de Diputados.

7 Melchor Ferrer: Historia del tradicionalismo español. Tomo XXVIII. Vol. I. Sevilla, Editorial Católica Española, 1959: 252.

8 La Correspondencia de España (8-III-1883).

9 Diccionario Biográfico Español, 2009-2013, Tomo VII: 186-189. 
Por otro lado, y confirmando estas anotaciones, en el Archivo Histórico Nacional hay unos expedientes conteniendo en detalle la pertenencia de este profesor palentino a distintas universidades, incluso con sus tesis doctorales en las facultades de Derecho y de Filosofía y Letras en la Universidad Central. ${ }^{10}$

\section{Cambios en la Situación política}

Se debe reconocer que, en los ochenta, Barrio y Mier ya era considerado un personaje importante dentro del carlismo. De hecho, en 1889, con ocasión de la composición de la Junta para la celebración del XIII Centenario de la Unidad Católica por la conversión de Recaredo, don Carlos lo designó como representante del reino de León. ${ }^{11}$ Asimismo, en otras ocasiones aparecía en primera fila, junto con otros dirigentes tradicionalistas, en distintas celebraciones en la capital, como la anual conmemoración carlista por los Mártires de la Tradición. Afirmando su importancia, el conde de Melgar, ${ }^{12}$ con ocasión del día de san Carlos, se quejaba ante el marqués de Cerralbo diciéndole que había algunos tradicionalistas relevantes que no habían felicitado al señor, como era Barrio y Mier. ${ }^{13}$ El 2 de agosto de 1891, Melgar volvía a escribir a Cerralbo diciéndole que desechaban la candidatura que él había propuesto para que Barrio y Mier fuera el director de El Correo Español, ${ }^{14}$ periódico al que don Carlos consideraba su gaceta oficial.

El 5 de marzo de 1890, se aprobó en España restaurar el principio de sufragio universal directo en todas las elecciones, ampliando de esta forma el número de posibles votantes. ${ }^{15}$ Por tanto, obviando la última guerra y el

10 Archivo Histórico Nacional -AHN-, Universidades, legajo 3663 exp. 17; legajo 5306 exp. 4; legajo 796 exp. 1; y legajo 6375, exp. 8, donde se encuentran algunos de los expedientes académicos, tesis doctorales y demás estudios de Matías Barrio y Mier.

11 Jordi Canal, «Recaredo contra la Revolución: El carlismo y la conmemoración del «XIII centenario de la Unidad Católica (1889)», en Carolyn P. Boyd (ed.) Religión y política en la Espana Contemporánea, Madrid, Centro de Estudios Políticos y Constitucionales, 2007: 254-255 y Javier Real Cuesta: El carlismo vasco, 1876-1900, Madrid, Siglo Veintiuno, 1985: 134.

12 Francisco Martín Melgar, conde de Melgar (1849-1926), secretario de don Carlos desde 1876, aunque oficialmente desde 1880. Finalmente fue destituido de su cargo en 1900.

13 Archivo Museo Cerralbo -AMC-, Manuscrito MS-E. 6490, Caja VI/32, Referencia -R-234.

14 AMC, MS-E. 6490, Caja VII /19 R. 261.

15 Luis Aguiar de Luque y José Manuel Sánchez Saudinós: «La obra legislativa. El perfeccionamiento formal del estado liberal y democrático», en Manuel Espadas Burgos (coord.) La época de la Restauración (1875-1902) Volumen I. Estado, Política e Islas de ultramar, tomo XXXVI de la Historia de España Menéndez Pidal, Madrid, Espasa-Calpe, 2000: 373-420. 
retraimiento, los carlistas, bajo la dirección del marqués de Cerralbo, prepararon sus 33 candidatos para las elecciones de 1891. De estos, tan solo fueron elegidos 5, entre ellos Barrio y Mier, que, en enero de 1893, en una de sus discursos en el Congreso, refiriéndose a los carlistas y respondiendo a distintas acusaciones, no dudaba en decir que: «nosotros no somos absolutistas, somos los menos absolutistas, rechazamos el absolutismo que condenamos con energía, reprobamos todos los absolutismos conocidos, somos partidarios de la libertad cristiana». ${ }^{16}$ En las siguientes elecciones, las celebradas el 5 de marzo de 1893 y el 5 de abril de 1896, los carlistas consiguieron 7 y 9 actas de diputado, respectivamente. Entre los elegidos en ambos casos figuraba el palentino Barrio y Mier. ${ }^{17}$

Posiblemente por las irresponsables declaraciones de algunos notables carlistas, en 1897, empezaron a circular noticias acerca del levantamiento de algunas partidas, supuestamente de seguidores de don Carlos. Defendiendo su Causa, era Barrio y Mier quien acusaba a los liberales de propagar rumores o de ser ellos mismos los autores de los levantamientos en su propio beneficio. Aseguraba que ellos, los carlistas, estaban más pendientes del desarrollo de los acontecimientos en ultramar, además de estar esperando órdenes superiores, y añadiendo que «pronto verán todos que no somos unos heraldos de la guerra civil, sino la reserva que Dios tiene dispuesta para salvar a España cuando parezca que ha llegado el momento de la catástrofe». ${ }^{18}$ Como hacían la mayor parte de los ilustres del carlismo, también Barrio y Mier era partidario de publicar declaraciones ambiguas, ya que lo mismo parecían decir que estaban preparando una sublevación, aunque esperando los resultados de Cuba y Filipinas, que, como amantes de la paz, solo deseaban respetar el orden establecido.

Las elecciones del turbulento año de 1898, se celebraron el 27 de marzo. Antes de estas, don Carlos, buscando más votos en favor de los suyos, había declarado que él era el único que podía solucionar los problemas que atañían a la nación. Sin embargo, en las mismas, los carlistas solamente

16 El Correo Español (29-I y 1-II-1893).

17 Miguel M. Cuadrado, 1969, Elecciones y partidos políticos de España (1868-1931). Madrid. Taurus Ediciones: 565 y 584. Congreso de Diputados «Índice Histórico de Diputados», figuran todas las ocasiones en las que fue diputado el profesor palentino. En las elecciones del 1 de febrero de 1891, logró 4.523 votos; el 5 de marzo de 1893, consiguió 4.418 votos; y en las del 5 de abril de 1896, 5.202 votos, en los tres casos por el distrito de Cervera de Pisuerga, y logrando casi el $100 \%$ de los votos emitidos.

18 El Correo Español (11-III-1897). 
consiguieron 5 diputados, entre los que, de nuevo, estaba Barrio y Mier elegido por Cervera de Pisuerga. ${ }^{19}$

En 1898, la derrota sufrida por España ante Estados Unidos y la firma del Tratado de Paz de París entre las dos naciones contendientes, supuso la pérdida española de Cuba, Puerto Rico, Filipinas y Guam. Esta pérdida sirvió de base para que la familia carlista, con su acostumbrada apología de la política de la violencia, ${ }^{20}$ iniciara preparativos para un verdadero levantamiento con el fin de defender a su nación ultrajada.

El 15 de enero de 1899, Melgar consultaba a Cerralbo, que continuaba en Francia por lo que Barrio y Mier ejercía una delegación interina, si las instrucciones sobre la actuación carlista en el Congreso al confirmarse el Tratado de Paz, se las debían enviar a él o a su sustituto. El 16 de febrero, como una muestra más de desaprobación a la actuación del Gobierno, Melgar comentaba a Cerralbo las órdenes que directamente habían cursado a Barrio y Mier para empezar un nuevo retraimiento de la minoría carlista y para que esta decisión se publicara en El Correo Español. ${ }^{21}$ En abril, se volvieron a celebrar nuevas elecciones en España. Con Cerralbo ausente y Barrio y Mier como delegado provisional, además de los acontecimientos del Desastre pesando demasiado sobre su opinión y pensando más en una insurrección general que en las urnas, en esta ocasión los carlistas obtuvieron uno de sus peores resultados. Lograron la escasa representación de tres diputados, repitiendo en el cargo Barrio y Mier. ${ }^{22}$

A finales del siglo XIX, además de las inquietudes levantiscas que se respiraban en distintos sectores del partido, en diciembre de 1899, se produjo la dimisión de Cerralbo. En consecuencia, don Carlos nombró a Barrio y Mier a todos los efectos como su representante en España. Así se debería publicar en El Correo Español, por lo que el 10 de diciembre, Barrio y Mier se ponía en contacto con el conde de Casasola, notable carlista y hermano de Cerralbo, para expresarle su sentimiento por la dimisión del

19 En cartas del marqués de Cerralbo a Polo y Peyrolón de 1898, le hablaba de los candidatos y de los resultados en estas elecciones, Real Academia de la Historia, colección Polo y Peyrolón, legajo 9/7901. En estas elecciones Barrio y Mier logró 4.527 votos a su favor, de los 4.572 que ejercieron el derecho.

20 Jesús Millán: «Popular y de orden: la pervivencia de la contrarrevolución carlista», Ayer, 38 (2000): 15-30.

21 AMC, MS-E. 6490, Caja XI/21, 26 y 34 R. 428, 433 y 441.

22 Congreso de Diputados «Índice Histórico de Diputados». El profesor palentino figura que en las elecciones del 16 de abril de 1899 logró 4.892 votos. 
delegado, anunciándole que tenía instrucciones de don Carlos de incluir al día siguiente en el periódico carlista la carta de la dimisión y su propio nombramiento. ${ }^{23}$

A partir de este momento, el pretendiente carlista empezó a mantener con su delegado una profusa correspondencia llena de detalles afectuosos, en los que, también es posible que quisiera hacer olvidar las cariñosas cartas que había dirigido a su anterior delegado, al que llegó a considerar como de su familia. Así, el primer día de enero de 1900, don Carlos se dirigía a su nuevo representante agradeciéndole que cumpliera todos sus encargos. El día 5, le escribía para, además de acusarle recibo de sus cartas, darle noticias de su hijo primogénito don Jaime. Sobre este, le insistirá a lo largo del año, facilitándole todo tipo de detalles del viaje que estaba realizando por tierras de Rusia y China y exigiéndole que publicara la noticia en «su periódico». ${ }^{24}$ Don Carlos, con estas publicaciones quería acallar los rumores de algunos jaimistas acerca de su posible transmisión y dejar claro que su hijo no quería despojarle de sus derechos.

Por su parte, Barrio y Mier intercalaba su actividad de delegado con sus intervenciones en el Congreso, su pertenencia a la Instrucción Pública y con su profesión de abogado. ${ }^{25}$ Asimismo, hay que señalar que debía ser, además de sencillo y talentoso, muy modesto, porque Conrado Muiños escribía «Es de lamentar que no tuviera superior que le obligara a comunicar por medio de la imprenta los frutos de su luminoso ingenio, que su modestia ocultaba». ${ }^{26}$

En verano de 1900, Barrio y Mier se había retirado a Cervera para descansar. Pero queriendo afianzar su poder como máximo representante del rey y mostrar distancias, destituía de todo cargo y representación en el carlismo a Mata, presidente de la diputación provincial de Navarra, porque había tomado parte en los obsequios que se habían tributado en Pamplona al diputado conservador marqués de Vadillo. ${ }^{27}$ Pero como la situa-

23 AMC, MS- E. 6490, Caja XV/19 R. 616. Hay que hacer hincapié en que toda la correspondencia perteneciente a Matías Barrio y Mier que se cita en este trabajo, está manuscrita por el propio pretendiente y se encuentra en el Archivo del Museo Cerralbo.

24 AMC, MS-E. 6490, Caja XVI núm. 5, 7, 8 y 9 R. 635, 637, 638 y 639.

25 La Época (17-I-1900) Heraldo de Madrid (28-I-1900), La Correspondencia de España (16-II-1900), además de El País y El Siglo Futuro a lo largo de 1900.

26 Froilán de Lózar: «La aventura política de Matías Barrio y Mier», Publicaciones de la Institución Tello Téllez, 78, Palencia 2007: 165-264.

27 El Día y El Liberal (2-VIII-1900) y El Correo Español (3-VIII-1900). 
ción interna de los carlistas en Madrid no debía estar totalmente aclarada, don Carlos no cesaba de prevenir a su delegado y le presionaba para que desmintiera ciertas noticias que circulaba por la capital. Así, el 6 de octubre de 1900, con el partido inmerso en una nueva sublevación, le advertía sobre algunos rumores que decían que nuevamente el duque de Madrid le iba a dar los poderes a Cerralbo, ${ }^{28}$ afirmando categóricamente que no había nada de verdad, e insinuando que él ya sabía de dónde procedían estas noticias, aunque no desvelaba la procedencia. Por tanto, le decía a Barrio y Mier, que creía necesario reforzar su autoridad, por lo que le pedía que le dijera la forma que le pareciera más convincente pensando en el bien de la Causa, pero prescindiendo de modestia. ${ }^{29}$

\section{LA OCTUBRADA Y SUS CONSECUENCIAS}

Como se viene diciendo, en los últimos años del siglo XIX, dentro del carlismo se vivía una situación de «presublevación». De hecho, la correspondencia mantenida entre los distintos dirigentes carlistas mencionaba, sin ningún tipo de censura, una próxima «guerra civil», hablando de los preparativos de una insurrección general en la que, inicialmente, estaban implicados como principales promotores, tanto el conde de Melgar, como el marqués de Cerralbo. ${ }^{30}$ Sin embargo, siguiendo las instrucciones de don Carlos, que continuaba con la ambigüedad, El Correo Español protestaba diciendo que ellos abogaban por la paz legal a pesar de que las publicaciones liberales dijeran que los carlistas querían la guerra. ${ }^{31}$

Por su parte, y como algo que debía estar en su idiosincrasia, a principio de octubre de 1900, los carlistas residentes en París, entre los que se encontraba Cerralbo, debían estar preparando una «serie de graves acontecimientos», aunque los de España lo negaban. Sin embargo, el Gobierno español, en un país que en aquel año tenía distintos puntos neurálgicos, cualquier preparativo de conspiración o levantamiento que afectara a España, se produjera donde se produjera, pronto se abortaría. ${ }^{32}$ De hecho, se

28 La Época (2-X-1900). La noticia era recogida, ese mismo día o sucesivos, por distintos periódicos, aunque, como será habitual, solo se citará uno de ellos.

29 AMC, MS-E. 6490, Caja XVI/11, R .641.

30 Agustín Fernández Escudero, 2015, El marqués de Cerralbo. Una vida entre el carlismo y la arqueología, Madrid, La Ergástula: 269-270.

31 El Correo Español (15-IX-1900).

32 Jordi Canal y Eduardo González, «No era la ocasión propicia... La conspiración carlista de fin de siglo en un memorial a don Carlos», Hispania, 52: 181 (1992): 705-742. 
sabía que los llamados parisinos, estaban recogiendo fondos para la Causa, por lo que se aumentó la vigilancia sobre ellos. Asimismo, de acuerdo con la información que recibía el Gobierno desde el consulado de Venecia, también se extremaba el control sobre don Carlos. ${ }^{33}$ Hay que recordar que era la organización y capacidad movilizadora lo que mejor había desarrollado el carlismo, algo que era muy relevante en el contexto del espacio público en los momentos del cambio de siglo. ${ }^{34}$

Definitivamente, fue entre los días 28 al 30 de octubre de 1900, cuando empezó el «verdadero levantamiento» que se llamó La Octubrada. Se inició en Badalona y siguió en otras pequeñas localidades catalanas, ${ }^{35}$ aunque en ningún caso llegó a ser de más de veinte personas. El Correo Español se hacía eco de la noticia y el 28 de octubre publicaba a toda página «iPor fin es verdad el levantamiento de armas!». Estos ataques al orden también los recogía la prensa liberal tratando de perjudicar al carlismo. Barrio y Mier, continuando con su ambigüedad, se apresuró a anunciar que los individuos que se habían lanzado al campo no obedecían órdenes superiores pero que, si los carlistas pudieran, llevarían a cabo un gran movimiento. Así que, añadía, levantar unas partidas en Cataluña era, sencillamente, de tontos. En otro momento, aseguraba que estos sublevados no eran carlistas y que podía afirmar, como se decía en Barcelona, que la operación obedecía a los intereses de algunos para hacer bajar la bolsa española. ${ }^{36}$ Con la teoría del mercado bursátil coinciden distintos autores, aunque cuesta creerlo cuando algunos dirigentes carlistas reprochaban a sus compañeros haber efectuado este movimiento y, por otra parte, el mismo don Carlos les amenazó por haber hecho algo que él no había ordenado y que quería llevar a cabo más adelante, con todo organizado.

Según Melchor Ferrer, que ofrece un pormenorizado detalle de cómo se produjeron los acontecimientos, don Carlos no daría la orden de levantamiento, así, si el movimiento empezaba sin una orden real, permitiría, si

33 Archivo General de la Administración, Expediente (10) 000 54/16908, "Correspondencia varia relativa a manejos carlistas. 1897-1900» y Archivo Ministerio de Asuntes Exteriores y Cooperación, Fondo Política Interior, serie carlismo, signatura H-2846, año 1900, expediente I «Intentona carlista en Cataluña a fines de octubre de 1900 », contienen una amplia documentación sobre estas vigilancias.

34 Jesús Millán, 2000: 15-30.

35 Josep Carles Clemente: Historia general del carlismo, Madrid, Artes Gráficas S. Gómez, 1992: 353.

36 La Vanguardia (30-X-1900). 
este fracasaba, que el pretendiente quedara en posición de desautorizarlo, ${ }^{37}$ a pesar de que, por sus distintas declaraciones, él estaba totalmente enterado de lo que se estaba tramando, pero siempre pensando en un levantamiento general, como se lo venía declarando a Mella ${ }^{38}$ y al general Sacanell. ${ }^{39}$ Está razón que aduce Ferrer podía ser una por la que don Carlos menospreciaba y no cesaba de criticar a los componentes de La Octubrada, además de que, como se viene reflejando, él estaba preparando algo más importante, donde iba a ser el protagonista y no asimilaba que se le hubieran adelantado.

Lo cierto fue que, gracias a este frustrado intento, se desató una gran demostración de represión hacia los carlistas. Además, las autoridades, aprovechando los cambios que se venían produciendo en los puestos del organigrama, desmantelaron su estructura política y social clausurando sus círculos y cerrando El Correo Español y la casi totalidad de los periódicos tradicionalistas. ${ }^{40}$ También se hicieron distintos registros domiciliarios, entre ellos en la casa del delegado carlista, pero sin ningún resultado. Solo se encontraron algunas cartas de don Carlos, pero, según las autoridades, en ellas no se hacía alusión al movimiento carlista iniciado en Badalona. ${ }^{41} \mathrm{~A}$ partir de esta represión, que sumió al carlismo en una nueva crisis, según denunciaba el ministro de la Gobernación, Barrio y Mier dejó de asistir a los debates parlamentarios, aunque posiblemente lo haría como respuesta a la forma de actuar de la policía.

Por su parte, el rey quería dejar claro, ante los ojos del mundo entero, su no implicación en los últimos eventos de Cataluña. Pero, por otro lado, también quería mostrar que él continuaba siendo el único pretendiente al trono español, con unos derechos a los que no pensaba renunciar y para dejar constancia ante los seguidores de su hijo, que este tampoco, ya que estaba viajando por tierras lejanas. En dos escritos del 2 de noviembre de

37 Ferrer, 1959: 260-266.

38 Juan Vázquez de Mella (1861-1928) fue un periodista y político asturiano, descubierto por el marqués de Cerralbo, quien lo llamó a Madrid para que se incorporara a la redacción de El Correo Español. Después hizo importantes labores dentro del partido, pero por sus desavenencias con don Jaime, en 1922 llevó a cabo la llamada 'escisión mellista.'

39 El general Sacanell fue ayudante de campo de don Carlos y tras la destitución de Melgar, pasó a ser, hasta su muerte en 1905, su secretario.

40 Jordi Canal: «La reconversión del carlismo (1876-1931)», en Aróstegui, Canal y Calleja, El carlismo y las guerras carlistas. Hechos, hombres e ideas, Madrid, La Esfera de los libros, 2003: 95-97.

41 El Día (2-XI-1900). 
1900, el pretendiente le hablaba a Barrio y Mier de los viajes de don Jaime desde Japón a Varsovia, donde decía que permanecería todo el invierno. El representante carlista se apresuró a anunciar la presencia de don Jaime en Polonia, y que entre la familia de don Carlos existía una buena armonía. ${ }^{42}$

Continuando con los eventos de octubre, don Carlos señaló a Barrio y Mier que aquello se había hecho en contra de sus órdenes y por falsos carlistas, que habían lanzado a infelices al campo antes de tiempo, para realizar un plan infame. Aseguraba que el tiempo lo probaría todo, y que «no escapará a tu penetración de quien estoy hablando, aunque no es el momento de citar nombres, que van saliendo en los periódicos y con la ayuda de Dios todos se sabrán». Le recomendaba que, por consiguiente, permaneciese con los ojos abiertos, con el fin de cortar de raíz el mal en cuanto lo descubriese, pues Madrid —seguía el rey—, no era extraño a lo que había sucedido, así que debía informarle de cuanto supiese y considerase conveniente hacer. En sucesivos escritos, don Carlos continuaba pertinazmente dando muestras ante su delegado del desengaño por la fracasada intentona de Cataluña. El 7 de noviembre, comentaba que aquel pronunciamiento había sido realizado por traidores de la peor clase que habían explotado la buena fe y el entusiasmo de sus leales carlistas, queriendo hundir su Causa para beneficiarse ellos, precisamente cuando se estaban preparando para una acción verdaderamente seria, aunque, añadía que «todo se descubrirá, ya estoy sobre la pista». ${ }^{43}$ En definitiva, que el pretendiente no ocultaba su idea de hacer una sublevación en España a nivel general, pero organizada y dirigida por él, y contando con el dinero y apoyos militares suficientes. El 16 de noviembre, don Carlos seguía pasando instrucciones a su representante. Le hablaba sobre la reacción de los diputados y senadores carlistas, advirtiendo de que en aquellos momentos «nuestra actitud debe ser de la más absoluta y verdadera indiferencia». Volviendo a recordar a los que sufrían por las faltas de unos cuantos, pidiéndole que tratara de consolar a esos infelices. ${ }^{44} \mathrm{El} 4$ de diciembre, le indicaba a Barrio y Mier que era indudable que la intentona de Cataluña había sido obra de verdaderos traidores, por lo que era preciso estar prevenidos para que no les sorprendieran de nuevo. Afirmaba que desde París y Madrid había salido «el impulso criminal de aquel movimiento», hecho que estaba ocasionando múltiples falsas noticias, calumnias y rumores intencionados que

42 La Época (25-IX-1900).

43 AMC, MS-E .6490, Caja XVI núm. 13 R. 643.

44 AMC, MS-E. 6490, Caja XVI núm. 16 R. 646. 
costaba creer, pero que era su deber desbaratar los hipócritas planes que intentaban anular la Causa a la que se habían consagrado y que "yo sostendré, con la ayuda de Dios, mientras viva».

No obstante, y siguiendo fiel al primer término del lema de su bandera «Dios, Patria, Rey» y como una muestra de su sentido religioso, le decía a su delegado que había pedido permiso al papa con el fin de poder celebrar una misa en la capilla de su palacio, para rezar por el nuevo siglo y porque los carlistas permanecieran fieles. ${ }^{45}$

\section{El CoRReo Español}

Dada la importancia que tenía la prensa para los fines propagandístico del carlismo y con el fin de acercarse a las masas tradicionalistas, desde la creación de El Correo Español en 1888, una vez que el pretendiente había cambiado de delegado en España, proseguía en su empeño de controlar «su gaceta» y en especial al personal que componía su dirección. Así, don Carlos lo repetía en distintos escritos a Barrio y Mier, dejando constancia de que este periódico era indispensable para poder seguir en contacto con sus fieles seguidores, con el fin de transmitir órdenes y propagar consignas, en unos momentos de difícil situación en la política nacional y en su partido, a pesar de lo gravoso que le resultaba su mantenimiento. Así, el 18 de marzo de 1900, continuaba insistiendo ante su representante en relación con $E l$ Correo Español, a la vez que aprovechaba la ocasión para escribir sobre patriotismo y dejar testimonio de que él había dedicado toda su vida a España. ${ }^{46}$ Sobre el periódico carlista, continuaban siendo múltiples los escritos desde Venecia hacia Madrid. El 2 de agosto, el rey decía a su delegado que dejaba a su discreción aclarar los temas internos sobre la dirección de un diario que, además de tener sobre él cada vez menos control, le estaba costando un importante capital del que no disponía y que tenía que pedir prestado. ${ }^{47} \mathrm{El} 22$ de septiembre, le volvía a insistir encargándole para que se ocupara él personalmente de la marcha política del periódico, añadiendo un tajante: «El marqués de Cerralbo no tiene que ver más que en la parte administrativa y tú eres hoy la persona que me representa y recibe mis instrucciones». ${ }^{48}$ Como muestra de cambio de parecer, se puede recordar

45 AMC, MS-E. 6490, Caja XVI núm. 12 R. 642.

46 AMC, MS-E. 6490, Caja XVI núm. 6 R. 636.

47 AMC, MS-E. 6490, Caja XVI núm. 7 R. 637.

48 AMC, MS-E. 6490, Caja XVI núm. 10 R. 640. 
que, en 1891, don Carlos había dicho a Cerralbo, su delegado en aquel momento, que rechazaba la candidatura de Barrio y Mier como director del periódico carlista. Además, el pretendiente, en aquellos momentos, en teoría, no se atrevería a quitar la administración de El Correo Español a Cerralbo, ya que este, en los últimos años, había prestado importantes cantidades de dinero para la actividad del mismo. ${ }^{49}$

Dejando claro cómo aumentaban sus preocupaciones por El Correo Español, don Carlos le volvía a advertir a Barrio y Mier que tuviera mucho cuidado con su marcha política y le pedía que hiciera lo necesario para destituir a Mella como director, para antes de que se levantara la suspensión del periódico, que al igual que otros tradicionalistas, había sido retirado tras los acontecimientos de octubre de 1900. En un escrito del 14 de noviembre, le aconsejaba acerca de la selección de personal para El Correo Español. Añadiendo, el 27 de noviembre, que él pensaba que el diario pronto estaría en la calle, por lo que era necesario y urgente poner al frente a un director que fuera carlista, honrado, activo, disciplinado y enérgico. Mientras tanto, habría que nombrar a uno interino para sustituir a Mella, además de que «no conviene que Cerralbo siga teniendo la alta dirección en la administración». ${ }^{50}$ Se desconoce el motivo de este cambio de opinión del pretendiente, aunque se supone que no sería porque le había devuelto al noble el importe de todas sus entregas. El 8 de diciembre, don Carlos nombraba como director interino a Bolaños, dándole instrucciones a su representante para que la propiedad que tenía Mella pasase al palentino. El día 16, aprobaba los proyectos enviados por su delegado que «servirán para contrarrestar los manejos de los malos y de los tontos». ${ }^{51}$ Con todos estos escritos, el pretendiente carlista revelaba a su delegado la importancia que, para él, continuaba teniendo El Correo Español.

El 9 enero de 1901, el rey, queriendo dirigir todo desde su exilio, recomendaba a Barrio y Mier acentuar la nota religiosa del periódico con un credo más católico, además de político y modernista. También le decía que le volvía a remitir dinero para que continuara publicándose. El 12, le advertía de la llegada a Madrid del marqués de Cerralbo y de que él, como su delegado, debería tener en su mano todo lo relacionado con su gaceta. El 18, insistía en que Bolaños debía suplir a Mella para que este cesase en su

49 Fernández Escudero, 2015.

50 AMC, MS-E .6490, Caja XVI núm. 14, 15, 18 y 21 R. 644, 645, 648 y 651.

51 AMC, MS-E. 6490, Caja XVI núm. 19, 20 y 22 R. 649, 650 y 652. 
cargo en el periódico. Al terminar enero, nuevamente le remitía dinero para el funcionamiento del mismo, aunque para su control, ante la gravosa situación, le pedía un extracto de las cuentas. El 12 de marzo de 1901, tras la sanción, El Correo Español reinició sus ediciones, por lo que don Carlos felicitaba a su delegado, pero insistiendo en que no quería volver a ver el nombre de Mella en ningún artículo. ${ }^{52}$

\section{LA LUCHA TRADICIONALISTA A TRAVÉS DE LAS URNAS}

A finales de noviembre, según indicaba el pretendiente a su delegado, con el fin de mantenerlo al día de los acontecimientos del palacio del Loredán, había tenido que relevar de su puesto a Melgar. Así que, la correspondencia debía ser remitida directamente a él o por medio de Sacanell. Después de comentarios personales sobre su ya exsecretario, don Carlos terminaba mencionando que este había partido hacia París, dejándole a él los papeles de la secretaría. ${ }^{53}$

Con el inicio del año 1901, don Carlos seguía enviando cartas con instrucciones a su representante en España. Sin embargo, dada su importancia, le comunicaba por telegrama que su hijo había caído enfermo en Japón y que posiblemente fuera de fiebres tifoideas.$^{54}$ Es necesario destacar, como se viene reflejando, la obstinación de don Carlos relacionada con las estancias lejanas del "príncipe desterrado", como lo denominaban algunos de sus seguidores. ${ }^{55}$ Claro que esto no era óbice para que el pretendiente siguiera pensando que desde donde este estuviera podría alentar a sus fieles. Además, él no vivía ajeno a los rumores que circulaban sobre su posible abdicación en don Jaime.

El 18 de enero de 1901, don Carlos le escribía a su delegado sobre temas relacionados con las intrigas ocultas, tachando de mentiras e hijos del despecho los rumores y calumnias que circulaban relacionados con el tradicionalismo, advirtiéndole para que evitara que engañasen a los incautos. ${ }^{56}$ Es decir que, el pretendiente continuaba con su idea paternalista y de protección de sus «hijos».

52 AMC, MS-E. 6490, Caja XVI núm. 30 R. 660 del 9 de marzo de 1901.

53 AMC, MS-E. 6490, Caja XVI núm. 17/18 R. 647/648.

54 Heraldo de Madrid (6-I-1901).

55 Ferrer, 1959: 270.

56 AMC, MS-E. 6490, Caja XVI núm. 24/27 R. 654/657. 
Al poco tiempo, don Carlos, además de insistir ante su portavoz sobre la marcha de su gaceta, también le cursaba instrucciones para la próxima Fiesta de los Mártires de la Tradición, con el fin de que se siguiera recordando a los héroes que habían muerto por la Causa. Aquel año, como sucederá en los siguientes, aunque cambiando de iglesia, la celebración en recuerdo de estos mártires, que se había instaurado en 1896, tuvo lugar en la madrileña iglesia de San Ignacio, siendo el acto presidido por Barrio y Mier y por Feliú, ${ }^{57}$ además de otros ilustres del carlismo. ${ }^{58}$ Don Carlos, por su parte, seguía desmintiendo ciertas noticias relacionadas con la abdicación en favor de don Jaime aparecidas en la prensa española e italiana, asegurándole que su hijo había partido hacia Varsovia. A la vez, le volvía a prevenir contra «los funestos personajes que hijos del despecho faltaron a su fidelidad». .9

Sagasta, después de disolver las Cortes tras el cese de Azcárraga, convocó elecciones para el 19 de mayo de 1901. Al ser estas las primeras en las que Barrio y Mier participaba como delegado carlista, don Carlos le transmitió sus instrucciones y ánimos, diciéndole que debían presentarse diputados y senadores en tantos distritos como fuera posible, indicándole cómo debía actuar ante el ascenso de los republicanos. ${ }^{60}$ Hay que recordar que solo había transcurrido algo más de seis meses desde el revés de «La Octubrada».

El 1 de mayo, don Carlos felicitaba a su representante por el artículo que había publicado en El Correo Español en el que defendía la religión, la patria y la monarquía, a la vez que volvía a exigir a los suyos «el sacrificio de acudir a las urnas, a pesar de la mentira que encerraba el sistema parlamentario». Repetía que era necesario que los suyos aparecieran en todas las partes, incluso en las Cortes de la «mal llamada restauración, donde habría leyes execrables y blasfemas contra la religión». Concluía con «inculca estas ideas, por ser mi delegado en España, a los legítimos hijos de la Católica España». ${ }^{61}$

57 Bartolomé Feliú (Peralta 1849-Zaragoza 1918). Un resumen de su biografía se puede leer en: Agustín Fernández Escudero, 2015b «La delegación carlista de Bartolomé Feliú y Pérez (1909-1912) ¿Partidario de una nueva sublevación tradicionalista?», Studium, 21: 105-135.

58 Heraldo de Madrid (9-III-1901).

59 AMC, MS-E. 6490, Caja XVI núm. 28/30 R. 658/60 del 19 y 23 de febrero y 9 de marzo de 1901.

60 AMC, MS-E. 6490, Caja XVI núm. 31/34 R. 661/664 del 13, 20, 24 y 26 de marzo.

61 AMC, MS-E. 6490, Caja XVI núm. 35 R. 665. 
Pues bien, en estos comicios del 19 de mayo de 1901, a pesar de las recomendaciones desde Venecia, los carlistas solo lograron seis actas de diputado, entre ellas la de Barrio y Mier, que de nuevo dejaba constancia de su relevancia en Cervera. ${ }^{62}$ Este resultado fue considerado como una derrota por algún sector tradicionalista. Sin embargo, el delegado, en cuanto pudo, reunió a sus senadores y diputados para indicarles la conducta a seguir en los debates políticos. Fue en estos actos parlamentarios en los que se podía volver a encontrar ciertas intervenciones de Barrio y Mier en el Congreso; como su protesta defendiendo los servicios que había estado prestando a la nación española el papa León XIII o afirmando, tras diversas discusiones con Nocedal, que los carlistas eran católicos y que estaban en su derecho de manifestar públicamente sus creencias, a la vez que, también afirmaba que ellos eran regionalistas, porque esta había sido la constante tradición de la nación española, por lo que, se debería descentralizar la administración, dejando aparte las rencillas de los partidos ante «las desdichas que la Patria atravesaba». ${ }^{63}$ Mostrando su lado más personal, del que nunca se alejaba, tuvo su participación, dentro del Congreso, en el homenaje a Pi y Margall en noviembre de 1901, del que dijo que, a pesar de estar distanciado políticamente, la minoría carlista se unía al dolor por la muerte de tan ilustre persona. ${ }^{64}$

Sin embargo, la estructura interna del carlismo que tan bien había organizado el marqués de Cerralbo no debía funcionar, porque, los días 9 y 15 de agosto, don Carlos comentaba a su representante que sería necesario reorganizar el partido, uniendo lo civil y lo militar. ${ }^{65} \mathrm{~A}$ la vez, le prevenía de nuevo sobre las calumnias hipócritas, advirtiéndole sobre los traidores enemigos de la Causa. El pretendiente ordenaba a Barrio y Mier que con energía se opusiera a todo acto bélico y que públicamente desmintiera que se estaba organizando levantamiento alguno. ${ }^{66} \mathrm{El} 30$ de diciembre, prosiguiendo con las consecuencias originadas por «La Octubrada» y siempre queriendo dejar claro que él no había tenido nada que ver, le seguía hablando de los traidores, rebeldes, díscolos y de las infamias. ${ }^{67}$

62 Congreso de los Diputados, Índice Histórico de Diputados, muestra como Barrio y Mier logró 4.246 votos a su favor, de los 4.262 votantes, es decir, de nuevo casi un $100 \%$.

63 El Siglo Futuro (9-VII-1901) y El Globo (17-VII-1901).

64 El Liberal (1-XII-1901).

65 Esta organización de unir lo civil con lo militar no se ha visto que se hiciera en aquellos momentos.

66 La Época (8-X-1901).

67 AMC, MS-E. 6490, Caja XVI núm. 36/38 R .666/668. 
Como se ha dicho, don Jaime había caído enfermo en Japón. Fue hospitalizado en Niza, a donde se trasladó don Carlos, después de conseguir permiso de las autoridades francesas. El 24 de enero, le decía a Barrio y Mier que transmitiera a todos los carlistas su agradecimiento por sus oraciones para el restablecimiento de su hijo. ${ }^{68}$ Finalmente, don Jaime se fue restableciendo, según le decía a finales de mes el pretendiente carlista a su portavoz. A mediados de febrero, don Carlos, con su constante idea de acallar cualquier posible rumor sobre su abdicación y contra las intenciones de los seguidores de don Jaime, envió a Barrio y Mier una copia de la carta de su hijo para que la publicara en El Correo Español. En esta, don Jaime aseguraba que la enviaba a su rey porque, él, como su hijo, sería su primer súbdito y su primer soldado y porque quería agradecer las oraciones elevadas desde su patria a dios, durante su enfermedad. ${ }^{69}$ En otros escritos de febrero, don Carlos comentaba a Barrio y Mier que la mejoría de su hijo había sido lograda por las oraciones de los fieles carlistas, más que por las medicinas y las actuaciones de los médicos. ${ }^{70}$

Como muestra de normalidad, tratando de acallar rumores, pero dejando constancia de su labor al frente del carlismo, el marqués de Cerralbo, hizo, en marzo de 1902, unas declaraciones asegurando que Barrio y Mier era su digno sucesor y que estaba conservando la organización que él había imprimido al carlismo. ${ }^{71}$ Evidentemente, desconocía las instrucciones de don Carlos hacia su actual delegado.

A principios de abril, Barrio y Mier cayó enfermo y no volvió al Congreso hasta mayo, por lo que el diputado navarro Cesáreo Sanz fue su suplente en los distintos debates políticos. Asimismo, cuando se inauguró el nuevo Círculo Carlista en la madrileña calle Jardines, el delegado continuaba con problemas, y aunque ausente, fue nombrado presidente honorario del mismo. En verano, Barrio y Mier dejaba provisionalmente el control del partido al diputado Sanz. ${ }^{72}$

Los días 5 y 21 de abril, don Carlos, continuando con sus resentimientos hacia los traidores por los sucesos de Badalona, seguía haciendo refe-

68 El Siglo Futuro (20-I-1902) y La Correspondencia de España (23 y 25-I-1902).

69 El Correo Español (20-II-1902).

70 AMC, MS-E .6490, Caja XVI núm. 39/46 R. 669/676.

71 La Correspondencia de España (12-III-1902) y La Época (23-III-1902).

72 Noticias sobre las actividades de Barrio y Mier se podían leer en El Liberal (1 y 2-IV1902), El Día (14-IV-1902), El Globo (19-IV-1902), El Siglo Futuro (30-IV-1902), La Época (30-V-1902), El Imparcial (24-VI-1902) y La Época (20-VII-1902). 
rencia a su delegado, que permanecía enfermo, sobre quienes en los últimos años habían pagado sus bondades con ingratitudes e infamias. Pero no todo iba a ser protestar por la sublevación, ya que el 2 de mayo, adjuntaba a su delegado su reprobación acerca de la próxima ceremonia de coronación del rey Alfonso, para que fuera publicada en El Correo Español. Se trataba de una carta «A los españoles» en la que recordaba su protesta de hacía 16 años contra la proclamación de su sobrino Alfonso como rey de España. Decía que confirmaba, una vez más, la usurpación cometida a la muerte de Fernando VII, «último rey legítimo que había ocupado el solio de San Fernando», por lo que, solamente a él, le pertenecía el derecho a la corona española. Ahora, de nuevo, proseguía don Carlos, se le arrebataba esta con la mayoría de edad del titulado Alfonso XIII, según el triste y funesto legado que dejaba la regencia. Asimismo, seguía mostrándose como un hijo fiel de la Iglesia, español amante de su país, que luchaba contra la triunfante antisocial anarquía, pero asegurando que él con su lema de Dios, Patria, Rey podría restablecer el orden y la ley. ${ }^{73}$ La coronación de Alfonso XIII, que se celebró en mayo de 1902, despertó un extraordinario interés. Se prodigaron las noticias y detalles sobre la misma, con gran despliegue gráfico. Sin embargo, desde Venecia se tuvieron que desmentir los rumores que circulaban por Madrid de que, con motivo de la ceremonia, don Carlos había abandonado su palacio italiano para dirigirse a la frontera franco-española. ${ }^{74}$ Además, en España continuaban los distintos rumores acerca de un posible levantamiento de los carlistas y la prensa más liberal se esforzaba en airearlos y aumentarlos. Sin embargo, y como un paso casi castrense, en 1902 se habían creado en Madrid, y al año siguiente en Barcelona, los batallones de la Juventud. Estos eran grupos que ejecutaban marchas dando muestras de su instrucción militar, como percusores de los requetés que finalmente se llegarían a fundar en $1907 .{ }^{75}$ Cesáreo Sanz, delegado de hecho de don Carlos por la ausencia de Barrio y Mier, en aquel verano, declaró que la agitación de la que se hablaba no tenía nada que ver con ellos. Recordaba que estaba pasando como con «lo de Badalona, que ya entonces ellos afirmaron que no era por su culpa y que lo que sucedió había sido contraviniendo las órdenes de don Carlos». Si algún carlista se

73 AMC, MS-E. 6490, Caja XVI núm. 2 y 677/679 R. 632 y 677/679. Hay que tener presente que los liberales, que, tras la muerte de Sagasta en 1903, también tuvieron su crisis de liderazgo, en sus mandatos en el Parlamento, se encargaban de ir enfriando sus relaciones con la Iglesia.

74 La Época (14-V-1902).

75 Ferrer, 1959: 273. 
levantara ahora, proseguía el delegado en funciones, «también sería en contra de las órdenes de nuestro Rey». ${ }^{76}$

Pero la salud de Barrio y Mier empeoraba. Su cansancio era evidente, por lo que pedía a don Carlos que lo eximiera de su cargo. El 20 de diciembre de 1902, el pretendiente le contestó que su retirada en aquellos momentos resultaría fatal. Que otros le ayudarían, pero que debía seguir en su puesto hasta que llegara un mejor momento para relevarle. Continuando con su resentimiento hacia Cerralbo, aun cuando este noble siempre le había servido con verdadera fidelidad, le confiaba a Barrio y Mier que:

Una cosa debo advertirte y es que, nó por resentimientos ni odios que no caben en mi corazón, sino por razones serias, estoy resuelto á no confirmar la delegacion á Cerralbo, cuya eleccion indudablemente produciria, sobre todo en cierto circulo, la mas favorable impresion pero resultaria mas adelante fatal para la Causa que defiendo y por la cual tengo el deber de velar siempre. ${ }^{77}$

A finales de 1902, los tradicionalistas Llorens y Pradera, tras su regreso de Venecia, en una reunión de diputados y senadores carlistas en casa madrileña de Barrio y Mier, hicieron saber las instrucciones de don Carlos sobre el comportamiento de la minoría carlista en el Congreso, puntualizando que debería ser muy activa. ${ }^{78}$

\section{UNA JUNTA CENTRAL EFÍMERA Y EL ATAREADO BARRIO Y MIER}

Don Carlos, para aliviar la labor de su representante en España, pensó que lo mejor era instaurar una Junta Central que estuviera presidida por el propio Barrio y Mier y compuesta por los diputados y senadores carlistas, así como por los jefes regionales tradicionalistas. Así se lo comunicaba el 2 de enero de 1903, pero confirmándole que él, como su delegado, todo lo que dijera debía bastar, y que a él era a quien debían obedecer círculos y organizaciones tradicionalistas. En distintos escritos que don Carlos envió a su delegado en enero y febrero, insistía sobre el tema de la Junta y sus componentes. También, y dado que ese año de nuevo se iban a celebrar elecciones, le ordenaba que hiciera lo necesario para transmitir a sus segui-

76 El País (26-VII-1902).

77 AMC, MS-E. 6490, Caja XVI núm. 50 R. 680. Debe hacerse notar que en las citas se ha tratado de conservar la ortografía y puntuación de los documentos originales.

78 El Día (27/29-XII-1902). 
dores que debían acudir a la «llamada lucha legal que se avecinaba con nuestra bandera desplegada y en los puntos y en la forma que se les indicará». ${ }^{79}$ En estos comicios, los carlistas lograron siete actas de diputado, aunque Barrio y Mier no logró su elección en Cervera de Pisuerga, donde triunfó el candidato ministerial Ángel Gómez e Iguanzo de Cos. De hecho, El Correo Español, una vez conocidos los resultados y dejando constancia de la falta de limpieza en los mismos, publicó: «iQué vergüenza!» a la vez que criticaba al Gobierno.$^{80}$ En este escenario, se producía la anómala situación de que el delegado carlista no representara a su minoría en el Congreso, por lo que don Carlos ordenó a Barrio y Mier que designara como jefe a Enrique Gil y Robles, candidato electo por Pamplona. Asimismo, esta circunstancia hizo que Barrio y Mier continuara recibiendo cierta hostilidad desde algunos sectores tradicionalistas, por lo que volvió a pedir al pretendiente que lo relevara del cargo, ya que se consideraba incompetente, además de que, el número de los diputados electos demostraba que la Causa no estaba en su mejor momento. El 27 de mayo, don Carlos le contestó diciéndole que tan solo debía ser transparente con él, y añadía un categórico «Pero como tan solo deseas el bien del partido, te pido que continúes en tu puesto hasta que yo encuentre el momento oportuno para substituirte y la persona que con mejores circunstancias puedan reemplazarte». El representante admitió seguir al frente del partido, agradeciéndoselo su rey. Pero con el cambio, las cosas no acabaron de funcionar a nivel interno dentro del carlismo, ya que la Junta que don Carlos había visto como una solución y con carácter descentralizador, había nacido para tener una vida efímera. El 7 de julio, don Carlos se dirigió a su delegado para decirle que dado el mal resultado de las gestiones de la Junta, dejara las cosas como estaban anteriormente, que se lo comunicara a los integrantes de la misma y que lo publicara en El Correo Español. En posteriores escritos, el pretendiente carlista insistía ante su portavoz sobre esta Junta disuelta y citando cartas que había recibido de sus componentes. ${ }^{81}$

Don Carlos, desde Suiza, a donde se había trasladado por vacaciones, porfiaba ante a su delegado enarbolando su lema de Dios, Patria, Rey. En cartas del 8 y 10 de julio, le hablaba, entre otras cosas, sobre el nuevo pontífice Pío X. El día 22, y por distintos acontecimientos acaecidos en Francia con los legitimistas franceses y los rumores sobre su posible acceso al torno

79 AMC, MS-E. 6490, Caja XVI núm. 51/59 R. 681/689.

80 El Correo Español (27-IV-1903).

81 AMC, MS-E. 6490, Caja XVI núm. 60/66 R. 690/696. 
francés, aseguraba que él quedaría siempre como el primero de los españoles. El 24 de agosto, continuaba mostrándose intranquilo por las actuaciones de su hijo y le ordenaba que en su periódico no se publicase nada escrito por don Jaime, sin que previamente él lo hubiera revisado. ${ }^{82} \mathrm{El} 5$ de noviembre, don Carlos cursaba instrucciones a Barrio y Mier para que pusiera orden dentro del partido en Valencia, diciéndole que, como una muestra de su control sobre la situación en España, publicara en El Correo Español el desagrado con el que el rey veía los pactos que se estaban llevando a cabo en aquella región. Terminaba diciéndole que, si fuera necesario, pidiera dimisiones en los cargos. ${ }^{83} \mathrm{~A}$ partir de este escrito, son escasos los procedentes de Venecia, aunque entre los existentes, los temas seguían siendo los mismos: don Jaime y El Correo Español. De hecho, en mayo de 1904, Sacanell envió un telegrama a Barrio y Mier para, nuevamente, salir al paso sobre ciertas noticias relacionadas con don Jaime y confirmando que este permanecía en China. ${ }^{84} \mathrm{Y}$ el 7 de diciembre, el pretendiente escribía a su delegado sobre el tema de su periódico, anunciándole la ayuda que con Polo y Peyrolón le enviaba para organizarlo. ${ }^{85}$

Como un análisis del partido carlista, en el Heraldo de Madrid del 15 de septiembre de 1904, se publicaba un artículo titulado «El Carlismo por dentro» en el que, al entrevistado, no se decía su nombre, se le hacían distintas preguntas acerca de unas declaraciones que había hecho don Jaime a un diario francés, y este las consideraba falsas. Continuaba en la entrevista haciendo un repaso a la situación del partido y dejaba claro que el representante en España del duque de Madrid era Matías Barrio y Mier «persona cultísima, distinguido catedrático y maestro en Derecho, abogado eminente, orador elocuente y castizo, pero que esas cualidades que le distinguían quedaban anuladas y sin valor alguno para los efectos de su representación, por su falta de entusiasmo y falta de fe en nuestra Comunión política, por lo que preconizaba la disolución del partido». ${ }^{86}$ Esta era una de las maneras de desacreditar a Barrio y Mier que tanto influían en su moral, y por la que, además de por su cansancio, le había pedido a su rey que lo relevara del cargo. Sin embargo, y como una forma de demostrar

82 AMC, MS-E. 6490, Caja XVI núm. 67/70 R. 697/700.

83 AMC, MS-E. 6490, Caja XVI núm. 71 R. 701. El Correo Español (6-XI-1903) publicaba las instrucciones.

84 La Época (31-V-1904).

85 AMC, MS-E. 6490, Caja XVI núm. 72 R. 702.

86 Heraldo de Madrid (15-IX-1904). 
una normalidad interna del partido, el día de san Carlos, el delegado reunía a lo más significativo del carlismo en Madrid y presidía una misa celebrada en el oratorio del Caballero de Gracia, para después proseguir con un banquete en el Círculo carlista. ${ }^{87}$

Caído el gobierno de Maura, Montero de los Ríos convocó elecciones para el 10 septiembre de 1905. En estas, los carlistas tan solo obtuvieron cuatro diputados, aunque entre los elegidos estaba, ahora sí, Barrio y Mier, por lo que podría volver a dirigir la minoría carlista en el Congreso, y al igual que había venido haciendo desde su primera elección como diputado, participar en votaciones de variada temática, discutiendo sobre presupuestos y sobre leyes relacionadas con el clero o el caciquismo de su distrito. ${ }^{88}$ Así fue que, durante toda la legislatura, eran habituales sus intervenciones en el Congreso, y también como presidente de una comisión agrícola, defender su tierra palentina. ${ }^{89}$ Por otro lado, y como una demostración más de su altruismo y tratando de beneficiar a los más desfavorecidos, se le podía ver perteneciendo a la comisión sobre el precio del pan. En distintos momentos, el atareado Barrio y Mier, además de mantener esa profusa correspondencia con su rey que se viene comentando, continuaba con sus otras ocupaciones como delegado y diputado carlista, proseguía con sus asuntos en los que él ejercía como abogado, pero es que, por añadidura, seguía estando inmerso en el mundo académico. Dentro de sus labores como catedrático, pertenecía a tribunales de oposiciones de distintas universidades, como la de Salamanca, o como decano de la Facultad de Derecho en la Universidad Central, participaba en la inauguración del curso escolar 1906/1907..$^{0}$ Una vez terminado el verano de 1907, Barrio y Mier regresó a Madrid desde su lugar de descanso y, como decano, participó en la apertura del nuevo curso académico. Incluso tuvo fuerzas para enfrentarse al conservador marqués de Vadillo, profesor y catedrático de Derecho Natural de la Universidad Central, y entonces gobernador de Madrid, impidiéndole dar sus clases, alegando que por ley estaba prohibido hacerlo mientras ocupara el cargo de gobernador. ${ }^{91}$

87 La Época (3-XI-1904).

88 Congreso de Diputados, Índice Histórico de Diputados, Barrio y Mier logró 4.129 votos.

89 El Día (31-X-1906).

90 El Imparcial (19-IX-1903 y 18-I-1904), El Siglo Futuro (30-XII-1903), Heraldo de Madrid (4 y 5-I-1904), La Época (16-III-1904). Diario Oficial de Avisos de Madrid (1-XII1905) y El Imparcial (2-X-1906).

91 El Siglo Futuro y El Imparcial (2/14-10-1907). 
De igual manera, aunque ya cansado, Barrio y Mier continuaba perteneciendo a distintas asociaciones y corporaciones religiosas, científicas y literarias, dejando patente en todo momento su catolicismo, su dinamismo y su ilustración. ${ }^{92}$

Por otro lado, en 1905, el partido tradicionalista continuaba con sus rencillas internas en las que habitualmente aparecía Mella, e indirectamente se veía involucrado Barrio y Mier. ${ }^{93}$ La prensa liberal, no solo aireaba estas discordias de partido, sino que también continuaba propagando rumores acerca de que los carlistas en Madrid se estaban encargando de organizar una nueva intentona golpista. Así resultó que el delegado, al salir de una misa, tuvo que asegurar que los rumores eran infundados. Además, don Carlos le telegrafió para que enérgicamente desmintiera la noticia, ya que los levantados no obedecían, bajo ningún concepto, órdenes suyas. Asimismo, circulaban noticias sobre que las dos ramas de la familia Borbón se estaban reconciliando, a lo que tanto Barrio y Mier como Mella dijeron que eran "paparruchas», ya que don Jaime había demostrado ser el primer carlista y seguía fiel a sus ideales.

En relación con el proyecto de Ley de Asociaciones (ley que según decía El Siglo Futuro, por ser anticatólica no solo era contraria a la voluntad del papa o de la Iglesia, sino también estaba en su contra el pueblo español), ${ }^{94}$ tanto Barrio y Mier como Llorens, en varias sesiones en el Congreso, mostraron su disconformidad con la propuesta que tanto limitaba a las órdenes religiosas y que provocó enfrentamientos entre católicos y republicanos en distintas manifestaciones de protesta. ${ }^{95} \mathrm{El} 21$ de diciembre de 1906, don Carlos escribía a su delegado acerca de «este proyecto de ley con el que el liberalismo pretendía manchar a España», indicándole que defendiera las órdenes religiosas a las que «tanto debía nuestra Patria». Le decía que hiciera saber a sus seguidores que:

yo permaneceré inconmovible en mi puesto de honor que por Su voluntad y el derecho tradicional me pertenece [...] nuestra Comunion fiel guardadora de las tradiciones patrias, debe figurar en la vanguardia de todas las manifestaciones de viril protesta que se hagan por la causa de Dios, cuyo Santisimo nombre figura al frente de nuestro lema inmortal. ${ }^{96}$

92 Diccionario Biográfico Español, 2009-2013: 186-189.

93 El Siglo Futuro (5-XII-1905).

94 El Siglo Futuro (3-XII-1906).

95 Ferrer, 1959: 291-292.

96 AMC, MS-E. 6490, Caja XVI núm. 73/75 R. 703/705. 
En consecuencia, el jefe de la minoría carlista aumentó el empeño en sus intervenciones en contra de la propuesta de esta nueva ley de Asociaciones, que durante tanto tiempo siguió discutiéndose en el Congreso. ${ }^{97}$

Por entonces, se produjeron dos hechos luctuosos: primero fue la muerte del viejo general Sacanell, acaecida el 13 de diciembre de 1905, siendo el propio don Carlos quien confirmó el deceso por telegrama a su representante, para que la publicara en El Correo Español. ${ }^{88}$ Segundo, en abril de 1907, falleció el integrista Ramón Nocedal. Barrio y Mier, dejando aparte sus enfrentamientos verbales, acudió, en compañía de Mella, a los funerales en la madrileña iglesia de la Concepción. ${ }^{99}$

En la primavera de 1907, don Jaime, tal vez alentando las ideas de cambio de sus jaimistas, hizo otro de sus viajes a España, visitando Sevilla y Madrid. En la capital se entrevistó con notables carlistas y conferenció ampliamente con Barrio y Mier. Más adelante, le preguntaron al delegado que cómo eran las relaciones entre padre e hijo, volviendo a asegurar que eran muy cordiales, ya que don Jaime profesaba una rendida admiración hacia su padre. ${ }^{100}$ En esta ocasión, don Carlos parecía obviar el resto de sucesos, y el 13 de abril, ante la importancia de los acuerdos aún por confirmarse con otras formaciones políticas, escribía a Barrio y Mier para que le comentara cómo había sido el encuentro celebrado en Madrid con algunos de sus principales seguidores, con el fin de tratar acerca de las elecciones que para el día 21 había convocado Maura. En estas, los carlistas lograron su mayor éxito en unos comicios, a partir del final de la última guerra, ${ }^{101}$ ya que gracias a su unión con Solidaritat Catalana obtuvieron catorce diputados. ${ }^{102}$ Entre estos elegidos volvía a figurar Barrio y Mier, que se encargaba de reunir a los tradicionalistas que habían conseguido su puesto en

97 El Imparcial o El Siglo Futuro, entre otros periódicos, de los últimos días de diciembre de 1906.

98 El Correo Español (14-XII-1905), recogiendo la noticia y añadiendo una pequeña biografía del general.

99 El Globo (6-IV-1907).

100 La Correspondencia de España (12-IV-1907).

101 Antes de la última guerra carlista (1872-1876), los seguidores de don Carlos, precisamente bajo el reinado de Amadeo I, habían logrado mejores resultados. Consiguieron 51 diputados en las elecciones del 8 de marzo de 1871; y en las que se celebraron en 3 de abril de 1872, los carlistas lograron 38 actas. (Cuadrado, 1969: 110-111 y 138-139.

102 La Época (24-IV-1907). Congreso de Diputados, Índice Histórico de Diputados. Figura Barrio y Mier que en estas elecciones del 21 de abril de 1871 logró 4.345 votos a su favor. 
el Congreso para, una vez que lo nombraron jefe de la minoría, acordar la conducta a seguir en la Cámara, en especial las relaciones con las demás minorías que hubieran sido apoyadas por Solidaritat Catalana.

Los carlistas, satisfechos con este resultado electoral, celebraron un mitin en Madrid, donde se leyeron discursos. El de don Jaime lo leyó Barrio y Mier, añadiendo que, si los liberales habían dado por muerto al partido carlista, se había demostrado que tan solo estaba adormecido y que había despertado con más vigor. ${ }^{103}$ No deja de ser curioso que de nuevo se volviera a suscitar este tema, ya que durante el mandato del marqués de Cerralbo, fueron varias las ocasiones en las que salió a colación la muerte y resurrección del tradicionalismo. ${ }^{104}$ Es necesario añadir que gracias al ahínco del incombustible Barrio y Mier, se había superado la crisis del partido carlista de fin de siglo, recomponiendo y dinamizando la estructura, así como con los círculos, viejos y nuevos, que volvían a situarse en el corazón del carlismo, ${ }^{105}$ todo basado en la organización de su antecesor el marqués de Cerralbo, a pesar de no utilizar, como este, la propaganda ni la proximidad personal, ya que, durante los diez años que duró su delegación, no se han recogido noticias acerca de que hiciera ningún viaje de acercamiento a sus seguidores de la Península. Por el contrario, sí se ha comprobado cómo Vázquez de Mella, que ya había acompañado al marqués de Cerralbo en algunos de sus viajes, y que él mismo los hizo, en la década de los noventa, acompañado de otros carlistas, ${ }^{106}$ entre otros, en agosto de 1902, realizó una excursión por distintos puntos de Galicia, donde sus discursos fueron aplaudidos; o a Cataluña y Valencia, en julio de 1903; además de los pertinentes a Navarra, donde, haciendo alarde de sus dotes como orador, y por su candidatura como diputado, también aprovechaba para dirigirse a sus seguidores. Desde El Correo Español, se encargaban de publicar los recorridos y discursos del notable carlista. ${ }^{107}$

De igual manera, Barrio y Mier hacía lo necesario para presidir la fiesta en honor de don Carlos que se celebraba en el Círculo carlista, donde como muestra de cambio «se leyó poesía y se hizo música en honor al concurso femenino». ${ }^{108}$

103 El Globo (20 y 21-V-1907).

104 Fernández Escudero, 2015.

105 Jordi Canal: El Carlismo, Madrid, La Esfera, 2004: 256-257; Diccionario Biográfico Español, 2009-2013, Tomo VII: 186-189.

106 Fernández Escudero, 2015: 158-170.

107 El Correo Español (1, 12 y 14-VIII-1902; 7, 8 y 14-VII-1903; y 1-II-1904).

108 El Día (6-XI-1907). 


\section{LA MUERTE De MATías Barrio y Mier}

El primero de enero de 1908, don Carlos escribió a su representante para decirle que se iba de viaje a Egipto y para hablarle de otro de su hijo a Marruecos, añadiendo que «su manera de ser me aflige y no le he dado ninguna autorización. Si fuese a España sería una nueva desobediencia, pues se lo he prohibido terminantemente». ${ }^{109}$ Es decir, que el pretendiente al trono español —aunque por ley natural sabía que no le quedaban muchos años de vida-, seguía aferrado a su idea de conservar sus derechos hasta la muerte y temeroso de la actuación de su hijo y sus seguidores que se los podrían arrebatar antes de tiempo. Y para que los carlistas fieles notaran su interés por todo lo español, en mayo de 1908, por telegrama para que fuera publicado, le recordaba a su delegado el centenario de la independencia de España, asegurando que su alma evocaba aquel glorioso pasado y lloraba la actual desventura, pidiendo a dios que le concediera un porvenir hermoso como los verdaderos españoles deseaban. ${ }^{110}$

En el verano de 1908, empezaron a surgir rumores, desmentidos con preocupación desde Venecia, acerca de que don Carlos estaba enfermo y, de nuevo, sobre su posible abdicación. El 17 de noviembre, el rey envió un despacho a su representante para que hiciera público que eso nunca podría suceder. Afirmaba que «siempre sostendré incólume mis derechos, en los que veo una obligación sagrada, confiando en Dios y apoyándome en mis leales carlistas, para alcanzar el triunfo de nuestra Santa Causa». ${ }^{111}$

Pero en Madrid, Barrio y Mier, además de cansado también estaba enfermo. En julio, anunciaba a sus compañeros que, de forma provisional, dejaba la jefatura de la minoría carlista en el Congreso por su necesidad de viajar para tomar aguas. ${ }^{112}$ No obstante, en la apertura del curso académico de 1908/1909, de nuevo apareció el profesor en el Paraninfo de la Universidad ocupando su sillón de doctor de Derecho. ${ }^{113}$ Esta sería su última participación en un acto así. De hecho, a los pocos días, reunía a los diputados carlistas para anunciarles que, por motivos de salud, se proponía a dejar la jefatura de forma definitiva. Sus sustitutos temporales, después de varias especulaciones, fueron Bartolomé Feliú y Joaquín

109 AMC, MS-E. 6490, Caja XVI núm. 76/77 R. 706/707.

110 La Correspondencia de España (10-V-1908).

111 La Época (24-XI-1908).

112 La Correspondencia de España (6-VII-1908).

113 El Globo (2-X-1908). 
Llorens. En aquellos momentos era evidente que la energía de Barrio y Mier se debilitaba, y los médicos le diagnosticaron primeramente cáncer y en el último momento anemia general. ${ }^{114}$ A finales de enero de 1909, estos doctores le recomendaron que el invierno lo pasara en Andalucía. ${ }^{115}$ En consecuencia, si bien, el 19 de enero de 1909, El Siglo Futuro anunciaba que había salido hacia tierras andaluzas para restablecer su salud, a los tres días, decía que había sido hacia Alicante, desconociéndose el motivo del cambio de destino, pero, puntualizando que al partir había delegado los asuntos de su bufete y de su jefatura carlista. ${ }^{116}$ El profesor palentino, a pesar de las molestias del viaje, llegó a Alicante en un estado satisfactorio. Una vez en la ciudad, se fue restableciendo de su enfermedad, hizo visitas, junto con su esposa y el delegado carlista en la zona levantina, mostrándose muy complacido de su estancia. ${ }^{117}$ Pero, ya una vez de regreso en Madrid, se empezó a agravar su enfermedad, trasladándose a su hotelito en las afueras de la capital. Con su estado emperorándose notablemente, motivó que desfilaran por su domicilio las personalidades más relevantes del carlismo. ${ }^{118} \mathrm{El} 5$ de junio, recibió los sagrados sacramentos. Don Carlos y doña Berta telegrafiaron a la esposa del delegado para interesarse por su estado. En un momento tuvo una ligera mejoría y, según recogía La Época, dio órdenes de telegrafiar a todos los diputados y senadores ausentes de la capital para que vinieran con el fin de celebrar una reunión. Mientras duraba esta gravedad, en Madrid ya se hablaba de su posible sustituto en la delegación, aunque los carlistas desmintieron que fueran a elegirlo ellos, ya que este nombramiento dependía solamente de su señor. Así fue que, aunque se esperaba que recayera sobre Cerralbo la designación final de don Carlos, este nombró provisionalmente como su representante al profesor navarro Bartolomé Feliú. Esta designación, en los círculos carlistas, la calificaban como una desconsideración hacia Barrio y Mier, cuando todavía la providencia no había dispuesto llevarse al ilustre catedrático, además de que aseguraban que existían otros elementos tradicionalistas más significativos para este cargo. El Correo Español tuvo que salir en defensa de Feliú asegurando que, en un momento de mejoría, había sido el propio Barrio y Mier quien lo había designado

\footnotetext{
114 Lózar, 2007: 165-264.

115 El Globo (13-I-1909).

116 El Siglo Futuro (19 y 22-I-1909).

117 El Liberal (22-I, 10-V-1909); Diario de Alicante y Heraldo de Alicante (25-I-1909) y El Porvenir (27-I y 3-II-1909).

118 El Siglo Futuro (5-VI-1909).
} 
como su sucesor en el cargo. Algunos carlistas desmentían esta afirmación, que no pudo ser corroborada por el enfermo, ya que el día 23 de junio fallecía a las dos y media de la tarde. Después del óbito se celebraron misas en la capilla ardiente del domicilio donde había pasado sus últimos días. ${ }^{119}$

El entierro de Barrio y Mier fue presidido por Bartolomé Feliú, como nuevo jefe tradicionalista y en representación del duque de Madrid, además de por el hijo del finado, acompañados por otros amigos y por los senadores y diputados carlistas. ${ }^{120} \mathrm{El}$ cadáver embalsamado fue conducido, primero a la Facultad y desde allí a la estación del Norte, para ser escoltado hasta Verdeña. El convoy llegó a Palencia a la mañana siguiente, siendo recibido con fervor. Posteriormente se realizó el traslado hacia la capilla del Rosario de su villa natal, donde se celebraron los solemnes funerales por el eterno descanso del alma de tan ilustre palentino. ${ }^{121}$

Don Carlos telegrafió a Feliú para decirle que ordenara a sus seguidores que en todos los lugares se celebrara una misa por el eterno descanso de su delegado recién fallecido. También, el 26 de junio, le envió un telegrama personal para que lo publicara en El Correo Español. En el mismo le confirmaba en su cargo de forma definitiva. ${ }^{122}$

\section{Conclusión}

Una vez leído este artículo, se pueden, a modo de conclusión y contextualizando, hacer una especie de resumen analítico que puede dejar más clara, todavía, la situación del tradicionalismo en los años de cambio de siglo y los primeros del xx.

119 Los detalles sobre la evolución de la enfermedad, y la muerte de Barrio y Mier, así como de las opiniones sobre el provisional nombramiento de Feliú, mostrando la importancia del profesor palentino, se podían leer, en los periódicos tradicionalistas, progresistas, republicanos o moderados, como: El Siglo Futuro (5, 7, 8, 11, 18, 22 y 23 de junio de 1909); El Correo Español (4, 5, 7, 8, 9, 11, 14, 15, 16, 17, 18, 19, 21, 22 y 23 de junio de 1909); La Época (6, 7, 8, 9, 11, 12, 13, 14, 15, 16, 17, 19, 21 y 23 de junio de 1909); El País (7, 12, 15, 17, 21 y 24 de junio de 1909); y La Correspondencia de España (9, 10, 14, 18, 19 y 23 de junio de 1909).

120 El Liberal (26-VI-1909).

121 El Diario Palentino y El Diario de Palencia (24/26-VI-1909), incluían, además, su pequeña biografía.

122 Fernández Escudero, 2015b: 105-135. 
En el ámbito cronológico que, de forma especial, recoge este artículo (1899-1909), la transformación política que se estaba tratando de introducir en España en aquellos años de cambio de siglo, no acababa de ser asumido por los dirigentes carlistas. La crisis motivada tras la Octubrada de 1900 , vino a demostrar que, no solo existían diferencias entre el pretendiente, que, de forma ambigua y desde su residencia de Venecia, trataba de cohesionar a la masa de carlistas con sus más destacados seguidores, sino que, entre estos últimos, también existían diferencias a la hora de la forma de llegar a su rey. Aunque, en ocasiones puntuales, se podría decir que era por figurar ellos mismos más cercanos al poder de don Carlos, para, según su opinión, no compartida por otros correligionarios, terminar con el liberalismo que estaba acabando con la nación.

De hecho, los cambios que trató de introducir don Carlos, después de la dimisión del marqués de Cerralbo en 1899, con el nombramiento de Barrio y Mier, no fueron tales. Ya que, según se ha podido comprobar, el pretendiente se siguió apoyando en un carlista de abolengo, que ya había prestado sus servicios de forma interina, pero que, tras recibir el nombramiento definitivo, el rey lo hizo su confidente, pero que debía obedecerle ciegamente. A este, además de pedirle que continuara al frente de la Causa carlista, a pesar de que el viejo profesor le había rogado su relevo, le pedía, entre cariñosas frases, desmentir falsedades e infamias, y difundir ideas para reforzar su autoridad frente a los traidores. El 19 de enero de 1903, continuando con sus muestras de afecto, le decía de forma categórica que, él, como su representante y delegado, era el único que debía saber ciertas cosas. ${ }^{123}$ En definitiva, que le encomendó que solucionara los tres problemas que más le acuciaban y que se vienen repitiendo: quería que pusiera orden en el partido; que reorganizara El Correo Español; y que alejara los temores de que su hijo, apoyado por sus seguidores, le usurpara sus derechos dinásticos al trono.

No obstante, toda esta forma de proceder era una muestra de su continuismo. Era seguir gobernando a «su familia» eternamente, desde su perspectiva soberanista, con exaltación de la Patria, cuyo trono le pertenecía por la gracia de Dios, siempre de acuerdo con sus ideales heredados. De su legitimismo dejó constancia en sus protestas por la coronación, de Alfonso XIII en 1902, porque, insistía, la corona le pertenecía, mientras que, en el resto de España, la llegada del nuevo monarca era admitida por todos los demás partidos políticos.

123 AMC, MS-E. 6490, Caja XVI, núm. 11, 19, 37 y 54, R. 641, 649, 667 y 684. 
Por otro lado, no deja de ser destacable que, aunque el nuevo delegado Barrio y Mier no realizara viajes de propaganda para mostrarse más cercanos a las masas de leales a don Carlos que tanto echaban en falta la presencia de su exiliado rey, con el fin de continuar con la labor que tan bien había realizado su antecesor, sí se encargó de que la estructura organizativa que el marqués de Cerralbo había establecido, y que tanto alabaron propios y extraños, incluso temiendo por su calidad, continuara fortaleciendo al tradicionalismo tan debilitado por los levantamientos y partidas de los años finales del siglo XIX, y que tanto desacreditaron a los carlistas.

También hay que destacar que Barrio y Mier dividió su tiempo en acatar las órdenes de don Carlos y en utilizar la tribuna del Congreso - como diputado tradicionalista por Cervera de Pisuerga-, para defender sus ideales monárquicos-religiosos y los derechos de la jurisdicción que le había elegido en repetidas ocasiones. Asimismo, continuó con su labor académica y siguió ejerciendo como abogado de diversas causas, que en distintos momentos se reflejaban en la prensa madrileña. Pero el cansancio y una enfermedad irreversible acabaron con este palentino.

Es preciso destacar que, bajo el mandato de este nuevo delegado, y, gracias a su unión con Solidaritat Catalana que, en 1907, con una nueva Ley Electoral, había agrupado a los partidos catalanes en las elecciones de ese año, los tradicionalistas lograron un considerable éxito. Los partidos regionalistas catalanes que, desde 1899, estaban consiguiendo su espacio en el Parlamento, restaban protagonismo a los partidos turnantes. Este afán por mostrarse, se vio acrecentado por el problema social, que derivaba en huelgas y demás conflictos emanados de que, al haber perdido España sus colonias, los mercados desde la metrópoli se habían visto seriamente afectados. Problemas que se extendían en Cataluña y en el resto de la Península, por lo que, la pequeña burguesía, a nivel nacional, buscaba su apoyo en el Ejército, al que le reclamaban que decretara un estado de guerra a nivel nacional que les protegiera y que cuidara por sus beneficios.

Sin embargo, tras la muerte de don Carlos en julio de 1909, pocos días después de la de Matías Barrio y Mier, con la llegada de don Jaime, el hijo primogénito del pretendiente carlista al que había nombrado su heredero, se trataría de modernizar el partido. Aunque, el nuevo pretendiente a la corona española, desde el mismo principio de su puesta en escena como tal, y a pesar de que confirmó en sus puestos a todos los jefes carlistas (a partir de ese momento jaimistas), incluido a Feliú como su delegado, no tuvo éxito en sus proyectos, ya que se produjeron distintas crisis de liderazgo. Como muestra de esta situación, se puede hacer referencia a la falta 
de un delegado en España, cuando empezaron los problemas hacia Feliú y fue destituido, dado que no llegó a nombrar en el cargo al marqués de Cerralbo, sino que tan solo, en 1912, le hizo presidente de una Junta Superior Central. Estos cambios internos, con una Gran Guerra por medio, que desde los tradicionalistas manifestaron sus distintas preferencias por cada uno de los dos bandos, concluyeron en el cisma mellista, que Vázquez de Mella llevaba anunciando desde sus desencuentros con el propio don Jaime, desde el mismo momento del acceso de este al primer puesto que le había asignado su padre.

\section{REFERENCIAS}

Aguiar De Luque, Luis y José Manuel SÁnChez SAudinós, 2000, «La obra legislativa. El perfeccionamiento formal del estado liberal y democrático». En Manuel Espadas Burgos, coord., La época de la Restauración (1875-1902) Volumen I. Estado, Política e Islas de ultramar. Tomo XXXVI de la Hist. de España Menéndez Pidal. Madrid, Espasa-Calpe.

CANAL, Jordi, 2007, «Recaredo contra la Revolución: El carlismo y la conmemoración del «XIII centenario de la Unidad Católica (1889)». En Carolyn P. Boyd, ed., Religión y política en la España Contemporánea. Madrid, Centro de Estudios Políticos y Constitucionales.

Canal, Jordi, 2004, El carlismo. Madrid, Alianza.

CANAL, Jordi, 2003, «La reconversión del carlismo (1876-1931)». En Julio Aróstegui, Jordi Canal y Eduardo G. Calleja, El carlismo y las guerras carlistas. Hechos, hombres e ideas. Madrid, La Esfera de los libros: 87-103.

CANAL, Jordi y Eduardo GonZÁlEZ, 1992, «No era la ocasión propicia... La conspiración carlista de fin de siglo en un memorial a don Carlos», Hispania, 52/181 (1992): 705-742.

Clemente, Josep Carles, 1992, Historia general del carlismo. Madrid. Artes G. S. Gómez.

Cuadrado, Miguel M., 1969, Elecciones y partidos politicos de España (18681931). Madrid. Taurus Ediciones.

Diccionario Biográfico Español. Tomo VII. Madrid, RAE, 2009-2013.

FERNÁNDEZ Escudero, Agustín, 2015, El marqués de Cerralbo. Una vida entre el carlismo y la arqueología. Madrid, La Ergástula.

FERNÁNDEZ EsCudero, Agustín, 2015b, «La delegación carlista de Bartolomé Feliú y Pérez (1909-1912) ¿Partidario de una nueva sublevación tradicionalista?», Studium. Revista de Humanidades, 21 (2015): 105-135.

FERrER, Melchor, 1959, Historia del tradicionalismo español. Tomo XXVIII, vol. I. Sevilla, Editorial Católica Española. 
Francia Lorenzo, Santiago, 2000, «Territorio Perniano. Un manuscrito de Matías Barrio y Mier en el Archivo Capitular de Palencia», Publicaciones de la Institución Tello Téllez, 71 (2000): 455-468.

LózAr, Froilán de, 2007, «La aventura política de Matías Barrio y Mier», Publicaciones de la Institución Tello Téllez, 78 (2007): 165-264.

Millán, Jesús, 2000, «Popular y de orden: la pervivencia de la contrarrevolución carlista», Ayer, 38 (2000): 15-30.

Real Cuesta, Javier, 1985, El carlismo vasco, 1876-1900. Madrid, Siglo Veintiuno.

\section{Hemeroteca}

El Correo Español.

La Correspondencia de España.

El Día.

Diario de Alicante.

El Diario de Palencia.

Diario Oficial de Avisos de Madrid.

El Diario Palentino.

La Época.

El Globo.

Heraldo de Alicante.

Heraldo de Madrid.

El Imparcial.

El Liberal.

El País.

El Porvenir.

El Siglo Futuro.

La Vanguardia. 
